\title{
NEW TERRITORIAL COMMUNITIES OF RECREATIONAL SPECIALIZATION IN UKRAINE. PREREQUISITES AND REQUIREMENTS FOR ARCHITECTURAL-SPATIAL ORGANIZATION
}

\author{
Yurii Ohonok \\ Postgraduate Student, \\ Lviv Polytechnic National University, \\ Lviv, \\ Ukraine
}

Article DOI: https://doi.org/10.36713/epra6579

\begin{abstract}
Territorial development of settlements is important not only because of its special role in the socio-economic life of the state. Its importance is also connected with the fulfillment of Ukraine's commitments to harmonize the current legislation and quality of life standards with the requirements of the $E U$, cooperation with which remains one of the priorities of our country's European integration. The need for a modern comprehensive reassessment of the role of settlements in general in supporting the economic development of the region is due to the significant natural, resource-production, labor and other available potentials of the settlement environment. Ternopil region has a huge recreational potential, it is: natural resources, monuments of history and architecture, pilgrimage centers. All this attracts tourists, not only from Ukraine but also from abroad. The use of rich recreational resources will allow to build resorts, rest homes, tourist bases in Ternopil region, which in a short period of time can raise the economy of the region, welfare, recreation culture and improve the process and quality of population health recovery. Increasing the capacity of tourist and recreational infrastructure by attracting domestic and foreign investment is one of the priority areas of socio-economic and cultural development of Ternopil region in recent years. Increasing the share of inbound and domestic tourism, sightseeing should be an effective tool for economic growth of the region and increase its prestige in domestic and international tourism markets.
\end{abstract}

KEY WORDS: territorial formations, united territorial communities (UTCs), recreational specialization, recreation, architectural and spatial organization.

The purpose of the article: to explore the prerequisites and justify the requirements for the architectural and spatial organization of new territorial communities.

The following tasks are solved:

- Recreational potential and administrative-territorial changes in Ternopil region, Ukraine are characterized;

- new territorial formations with development prospects have been identified;

- selected UTCs of recreational specialization are characterized;

- the requirements to the architectural and spatial organization are substantiated. of study.

1. General characteristics of the object

Ternopil region is an administrative territorial unit of Ukraine with its center in the city of Ternopil. Located on the Podolian Upland, the southern border of the region runs along the Dniester River, the eastern - along the Zbruch river. The region occupies the eastern part of Galicia historic region and part of southern Volhynia historic region.

In the Ternopil region there are 1055 settlements, of which 18 have the status of cities, 17 urban-type settlements and 1020 villages.

The process that has been much talked about in the last decade in Ukraine, the reform of the administrative-territorial structure of the state, is now 
taking shape. The implementation of the reform will significantly affect the established settlement system in Ukraine, will change the functions of most settlements in the regions and open new prospects for the development of many of them.

The problem of forecasting and analyzing changes in functions becomes relevant, as well as outlining the ways of development of the most degraded settlements of regions (urban settlements), which during the Soviet period lost their historical role, and in the context of administrative-territorial reform, becoming usually administrative centers of new territorial communities, receive development prospects.

In the conditions of administrative-territorial reform on the territory of Ternopil region recreational resources should play a special role.

2. Characteristics of the recreational potential of the region (natural, historical, pilgrimage).

According to the register of the State Agency of Ukraine for Tourism and Resorts, 125 tourist enterprises operate in the Ternopil region: 25 tour operators and 100 travel agents and their number is growing every year. The number of employees employed in tourism and related industries in the Ternopil region is tens of thousands of people. Despite some achievements in the development, tourism industry needs further development and significant investment in its development.

Taking into account the natural and landscape conditions, historical and cultural heritage and the existing recreational and tourist infrastructure, the priority areas of tourism development in the region were identified, where investments should be directed, in particular: National Nature Parks "Dniester Canyon" and "Kremenets Mountains" ; Kremenets-Pochaiv and Berezhany historical and cultural reserves; "Ternopil Castles" National Reserve, cities of Ternopil, Berezhany, Borshchiv, Buchach, Terebovlia, Gusyatyn and Mykulyntsi resorts; Zarvanytsia village of Terebovlya district as a pilgrimage center. With such potential, tourism should be developed as a strategic sector of the economy of our region.

As of today, the material and technical base of tourist and recreational facilities does not meet modern requirements and requires significant investment for re-equipment and modernization. Today, the issue of increasing tourist flows to the region is directly related to the problems of organizing the accommodation of tourists and the construction of modern facilities for their service. The resource potential in small towns and rural areas is extremely underused. The level of provision of roads with tourist, service and information structure is also insufficient.

In summary, the development of tourism in the Ternopil region is hampered by: lack of recreation and entertainment industry (except Ternopil city), insufficient number of equipped places for short-term recreation of tourists, unsatisfactory condition of roads, lack of entrances to many popular tourist sites, unsatisfactory condition of most cultural heritage sites, insufficient provision of the tourism industry with highly qualified specialists and lack of systematic advertising and information support.

\section{Characteristics of administrative-}

territorial changes in the region and the formation of new entities.

The main difficulty in forming a new administrative-territorial structure of the region is that in Ternopil region, as well as in the Western region of Ukraine as a whole, settlement system is historically different from other territories of Ukraine, in which a significant proportion are small settlements. Within the Ternopil region, today, there are 1,053 settlements, including 1,017 villages (581 village councils) with 656.8 thousand inhabitants. The average number of inhabitants of one village is 643 people. The urban population is about $50 \%$ of the total population of the region.

Administratively and territorially, the region consists of 17 districts, 18 cities (including 4 of regional subordination, 14 - district subordination) and 18 urban-type settlements. According to the latest census, the total population of Ternopil region is 1 million 138 thousand people. The region covers an area of 13,832 square meters. $\mathrm{km}$., is $2.28 \%$ of the territory of Ukraine $(2.36 \%$ of the population of Ukraine).

On December 16, 2015, by the order of the Cabinet of Ministers of Ukraine №1391, the perspective plan of formation of territories of communities of the Ternopil region was approved. On April 22, 2020, the order of the Cabinet of Ministers of Ukraine approved the order with latest amendments.

When preparing the Perspective Plan for the Formation of United Territorial Communities (UTCs), the Ternopil Regional State Administration should, first of all, take into account that an integral part of administrative-territorial reform should be optimizing the territorial management system, streamlining relations between different levels of government, providing real opportunities for everyone to receive the maximum number of quality social and administrative services from the authorities at each level, efficient use of resource potential, sustainable development of territories, ability to adequately respond to social and economic challenges, and ultimately - to improve the living standards of every citizen in every urban or rural settlement.

The long-term plan for the formation of united community territories, submitted by the Ternopil Regional State Administration for approval 
to the Cabinet of Ministers of Ukraine, in general, did not fully meet both the above requirements and the Methodology for the formation of competent territorial communities. However, the Perspective Plan for the Formation of Territories of Communities of the Ternopil Region was approved by the order of the Cabinet of Ministers of Ukraine of December 16, 2015 № 1391-p. Given the passports of competent territorial communities (CTCs) (prepared by interested representatives of the communities themselves and identified by them as potential administrative centers), it is obvious that the region did not fully manage, as recommended by the Methodology of Formation of Capable Territorial Communities, a proper comparative analysis of communities, the conditions were insufficiently researched, and also the basic problems and tasks of the modern administrative-territorial system are not solved.

In determining the centers of communities and the territorial basis for the formation of an effective system of government, in the vast majority of cases, preference is not given to former district centers and other settlements, which residents of surrounding settlements have traditionally recognized as local centers of public, cultural, religious life, trade centers and objects of economic activity and the presence of investment-attractive areas.

The regional state administration did not take into account and did not use other information that is not contained in the passport of the CTCs - the location of the territorial community in the settlement system of the region; natural resource conditions of the community; significant disproportion in resource provision and levels of socio-economic development between administrative-territorial units of one level; availability of transport networks of regional and state importance; land structure; industrial potential; the opportunity for the community to provide residents with a full range of full-fledged socioeconomic, administrative, household and other services.
In summary, administrative-territorial reform should not be an end in itself (reform for the sake of reform) with the main purpose of quick reporting to the central executive bodies on resolving the issue of forming the Perspective Plan by merging two or three village councils into a territorial community, without considering a number of factors, which will significantly affect the continued full existence of such communities and which will in no way be able not only to improve the provision of services, but also to provide them in general. The reform practically does not take into account the presence of a strong tourist and recreational potential of the region, which can become a driver of economic prosperity of the region.

\section{Identification of new territorial formations of} recreational specialization.

For this study, it was decided to identify key territorial entities with large recreational resource.

To identify and characterize the new territorial formations with the predominant recreational potential graphic method was used and three schemes of Ternopil region were created.

Scheme №1 reflects the location of notable resource and tourist facilities in the Ternopil region. There are temples, architectural monuments, castles, ruins, caves, parks, gardens, etc. With the help of this scheme, the largest clusters of objects are identified and divided into three main categories: naturallandscape, historical-cultural, religious-pilgrimage (Scheme №2). This method was used to obtain eight main areas with the prospect of recreation.

These areas were selected for further analysis. In scheme №3, the obtained scheme №2 was combined with the scheme of the perspective plan of formation of territories of UTCs of the Ternopil region from April 22, 2020.

It was found that some of the promising areas do not belong to any of the new proposed communities. For these areas, it is recommended to create communities based on the available recreational potential. 


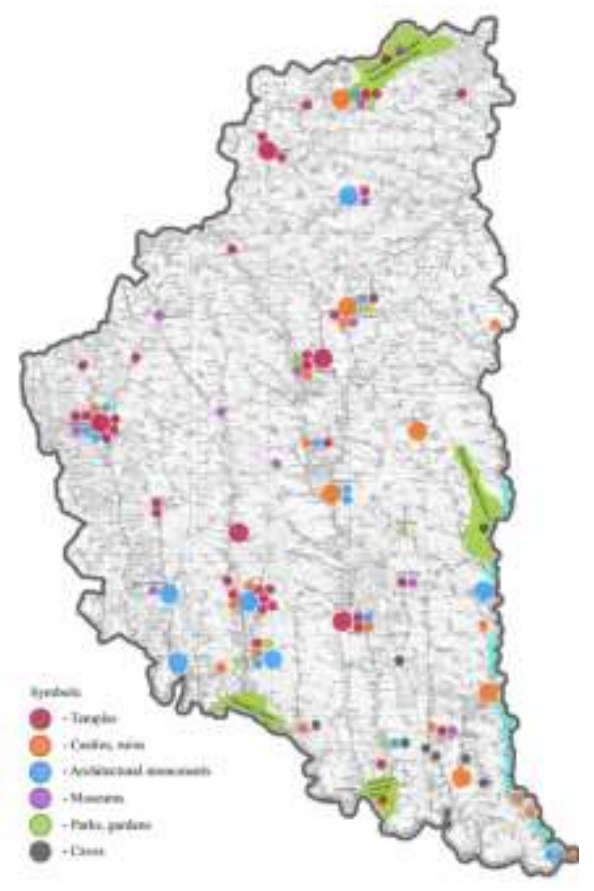

Scheme № 1

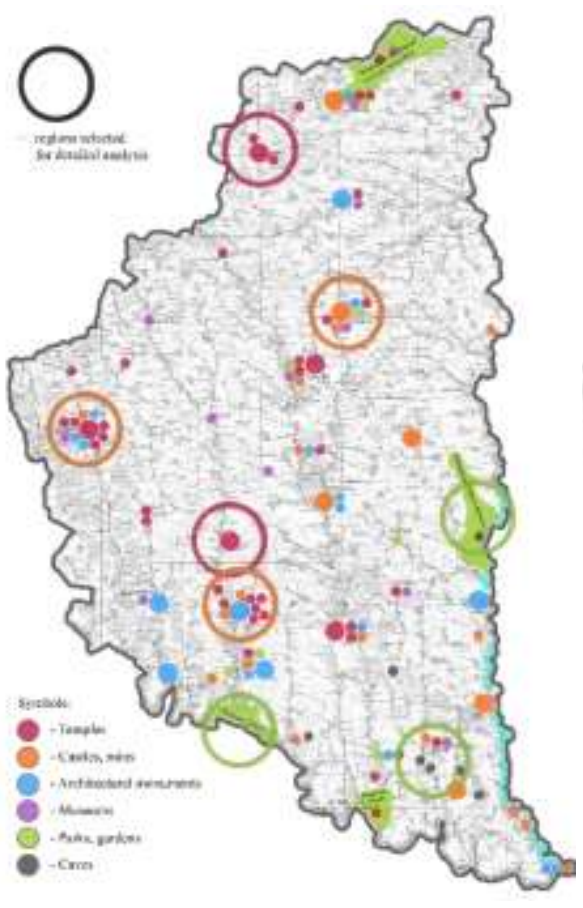

Scheme № 2

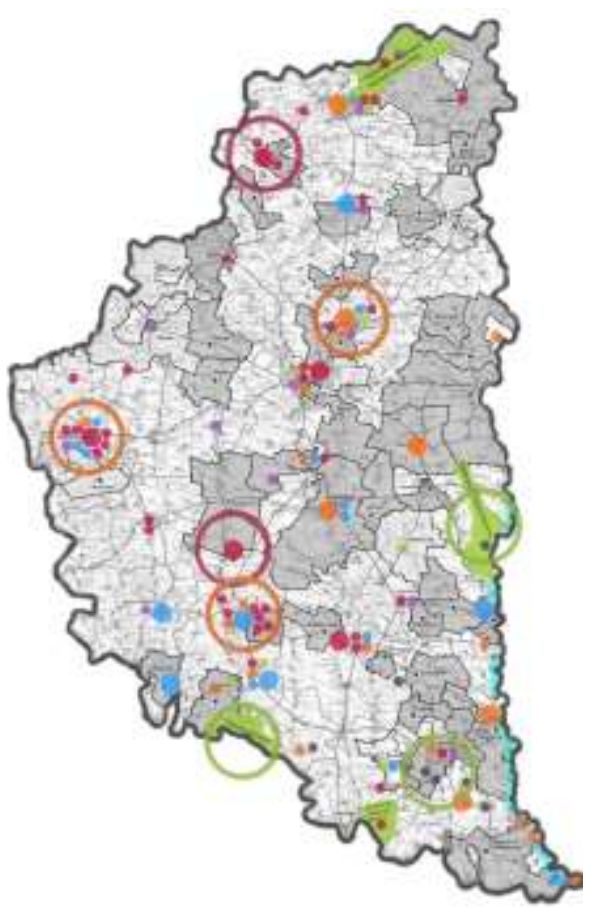

Scheme № 3 
EPRA International Journal of Multidisciplinary Research (IJMR) - Peer Reviewed Journal

ISSN (Online): 2455-3662

Volume: 7 | Issue: 3 | March 2021|| Journal DOI: 10.36713/epra2013 || SJIF Impact Factor 2021:7.147 ||ISI Value: 1.188

5. Characteristics of selected areas with recreational potential.

\begin{tabular}{|c|c|c|c|c|c|c|}
\hline $\begin{array}{c}\text { Recreational } \\
\text { potential }\end{array}$ & $\begin{array}{l}\text { Community } \\
\text { name }\end{array}$ & $\begin{array}{l}\text { The scheme of the } \\
\text { territory }\end{array}$ & $\begin{array}{l}\text { Number } \\
\text { of united } \\
\text { councils }\end{array}$ & $\begin{array}{c}\text { Area } \\
\text { (sq. Km) }\end{array}$ & $\begin{array}{l}\text { Pop-on } \\
\text { (people) }\end{array}$ & $\begin{array}{c}\text { Description of available recreational } \\
\text { potential }\end{array}$ \\
\hline \multirow[t]{2}{*}{$\begin{array}{l}\text { 1. Religious and } \\
\text { pilgrimage }\end{array}$} & $\begin{array}{l}\text { 1.1. Pochaiv city } \\
\text { UTC }\end{array}$ & & 2 & 54.2 & 9395 & $\begin{array}{l}\text { Orthodox monastery. The largest } \\
\text { Orthodox shrine in Volyn, the second, } \\
\text { after the Kiev-Pechersk Lavra in Ukraine. } \\
\text { For a long time - the Basilian monastery. } \\
\text { The Pochaiv Theological Seminary is } \\
\text { located on the territory of the Lavra. }\end{array}$ \\
\hline & $\begin{array}{c}1.2 . \\
\text { Zolotnykivs'ka } \\
\text { rural UTC }\end{array}$ & & 14 & 284.3 & 7976 & $\begin{array}{l}\text { Zarvanytsia Spiritual Center is a world } \\
\text { Marian pilgrimage center, one of the } \\
\text { largest shrines in Podolia of the } \\
\text { Ukrainian Greek Catholic Church. }\end{array}$ \\
\hline $\begin{array}{l}\text { 2. Historical and } \\
\text { cultural }\end{array}$ & $\begin{array}{l}\text { 2.1.Zbarazh } \\
\text { community }\end{array}$ & & - & - & - & Zbarazh Castle, fortification. \\
\hline $\begin{array}{l}\text { 2. Historical and } \\
\text { cultural }\end{array}$ & $\begin{array}{l}\text { 2.2. Berezhanska } \\
\text { city UTC }\end{array}$ & & 2 & 59.85 & 19784 & $\begin{array}{llll}\text { Brzezany } & \text { State } & \text { Historical and } \\
\text { Architectural Reserve. } & & \end{array}$ \\
\hline
\end{tabular}


EPRA International Journal of Multidisciplinary Research (IJMR) - Peer Reviewed Journal

ISSN (Online): 2455-3662

Volume: 7 | Issue: 3 | March 2021|| Journal DOI: 10.36713/epra2013 || SJIF Impact Factor 2021:7.147 ||ISI Value: 1.188

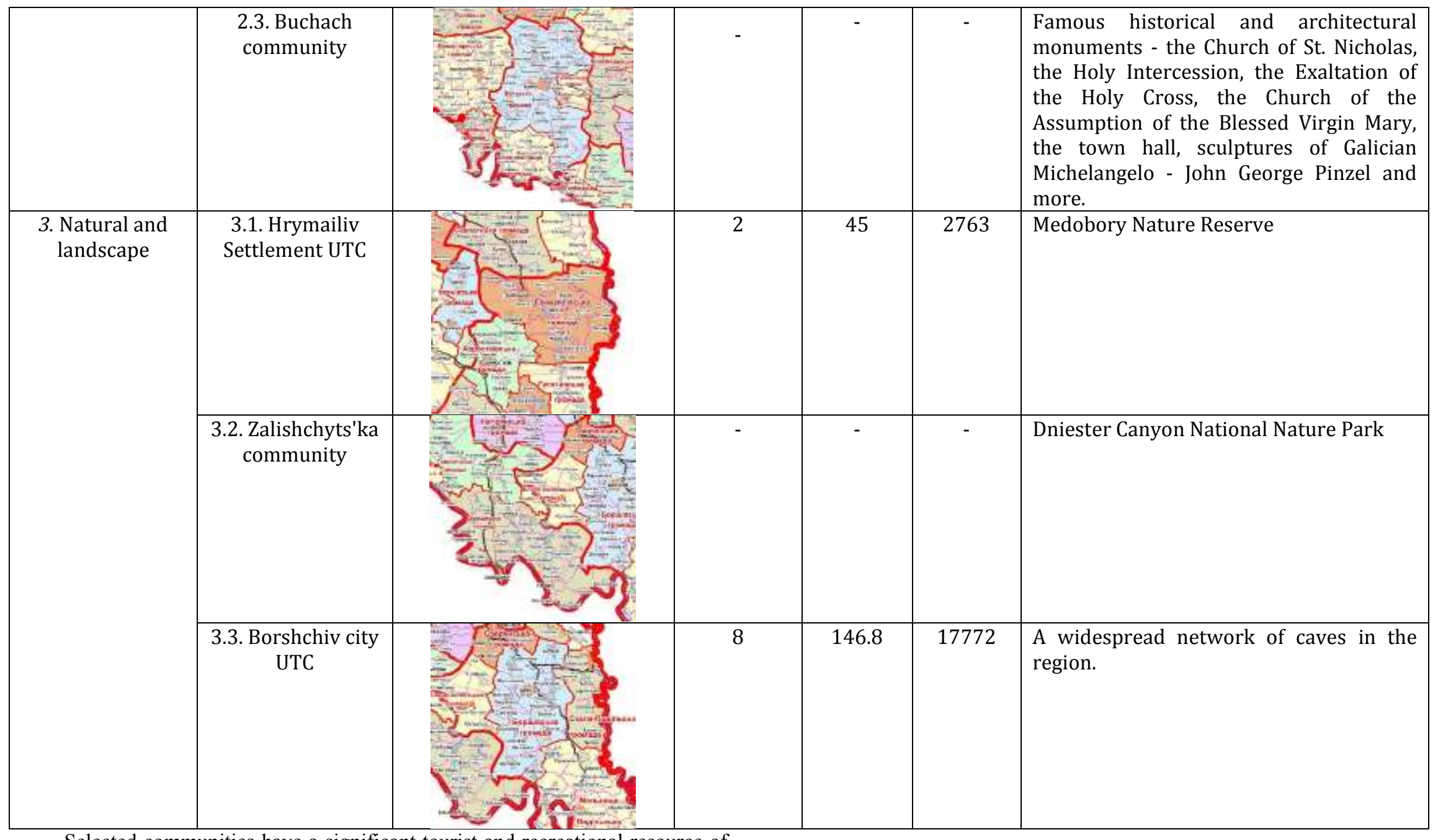

Selected communities have a significant tourist and recreational resource of various kinds. With proper administration aimed at the development of recreation and tourism, it is possible to improve the economic condition of these areas. This requires a comprehensive approach to the architectural and spatial organization of newly formed communities. 


\section{Substantiation of requirements to the architectural organization. \\ In their architectural organization, the new} territorial communities are not considered as a certain integral structure with internal and external connections and relations, as well as their multifaceted interactions. The community is interpreted as a set of relationships, connections and elements of urban space. This organization of spatial structures is associated with solving a set of complex problems. Therefore, it is important to outline the main functions (specialization) of individual territorial communities, and the corresponding requirements for their architectural and spatial development.

1. Focusing on new territorial entities with a dominant recreational function, we clarify the basic concepts for this specialization. Thus, recreation refers to the activities of people in their spare time, aimed at recuperation and recovery through participation in cultural activities, various forms of tourism and recreation in specialized areas. Recreation covers all kinds of activity in free time. Recreation usually also includes treatment and rehabilitation, that is all facilities related to this function, outside of permanent residence (sanatoriums, resorts, recreation centers, etc.). Recreational areas and objects are those areas and objects which, due to their natural, historical and ethnographic features, are attractive for visiting, treatment and recreation. These are mostly natural complexes that have preserved their unique characteristics and have healing and healthimproving properties (including monuments of history and architecture, reserves, reservoirs, travel routes, beaches, etc.). Attractive recreational resources affect the development of relevant areas. Architectural and landscape organization of recreational areas is an activity aimed at adapting the area to recreational functions. It includes three main aspects: protection of architectural and landscape properties of the region; ensuring conditions of communication accessibility of territories and objects; creation of infrastructural conditions for comfortable living, rest and rehabilitation both on places and on the road.

2. The main architectural and spatial characteristics of territorial formation are its territory, distances and location of the main elements in space. Thus, distances reflect the state of development of the road network and engineering infrastructure, and location - the nature of the location of individual zones. The basic problem of new territorial formations is the existing functional structure of the territory, which has developed historically. It is characterized by disorder and intertwining of zones of different functional nature - recreational, agricultural, urban, security, industrial.
3. Considering the architectural and spatial organization of new entities, we emphasize that changes in their spatial structure in recent decades have been due only to socio-economic transformations on a global scale (automation, reform of ownership, the formation of new cultural values, etc.). Architectural and spatial changes did not occur systematically and in many cases due to the deterioration of the environment.

4. With the implementation of administrative-territorial reform and the definition of key functions of new entities, it is necessary, first of all, to take into account the specifics and space requirements of individual objects that represent the main specialization. The organization of the space of these facilities will make them more attractive from a recreational and tourist point of view, which will facilitate the inflow of capital into the community. Proper zoning of the community will improve the perception of recreational facilities.

Improving the existing and creating a new road network and engineering infrastructure will make it possible to form close architectural, spatial and socio-economic links, both internal and external. This will increase the capacity of the recreational and tourist function of individual communities with this specialization and the region as a whole.

\section{CONCLUSIONS}

1. The recreational potential of Ternopil region is characterized and assessed. 2. The analysis of administrative-territorial changes in the Ternopil region is carried out and new territorial formations having prospects of development of recreational specialization are allocated.

3. The requirements to the architectural-spatial organization are substantiated: •Systematic requirement;

- functional sufficiency requirement;

- the requirement of landscape-spatial order;

- the requirement of advanced development of engineering and transport infrastructure;

- requirement of efficiency and ecological use of resource (recreational) potential.

\section{BIBLIOGRAPHY}

1. Dotsenko A.I. (2010), "Territorial organization of resettlement (theory and practice)" Phoenix, Kyiv.

2. Gabrel M.M., Nalyvayko J. (2008), "Methodology and framework conditions of spatial planning at the intraregional level. European experience for the practice of Ukraine." Scientific Bulletin of the National Agrarian University, vol.128, Lviv.

3. Vakulenko V.M., Mamonova V.V., Sharov Y.P. (2004), "Strategic planning at the local and regional levels: textbook." Patent, Uzhgorod.

4. Krishtop T.V.(2003), "Improving the territorial organization of the rural settlement network as a 
component of reforming the administrative-territorial structure of Ukraine." Experience and prospects of development of cities of Ukraine Methodical aspects of urban and regional planning, vol.5, KNUBA, Kyiv.

5. Udovichenko V.P. (2003), "New models of socioeconomic development of cities in terms of reforming market relations and civil society" Testament, Kyiv.

6. Resolution of the Cabinet of Ministers of Ukraine № 214. "On approval of the Methodology for the formation of able-bodied territorial communities" April 8, 2015.

7. Order of the Cabinet of Ministers of Ukraine dated December №1391-r. "About the statement of the perspective plan of formation of territories of communities of the Ternopil region." December 16, 2015.

8. Yavorsky G. (2004-2010), "Ternopil encyclopedic dictionary." Zbruch, Ternopil.

9. Pavlov O.I. (2009), "Natural resources of rural territories of Ukraine as the basis of their revival." Scientific Bulletin of Odessa State Economic University, vol. 13, Odessa.

10. Petranovsky V.L., Rutinsky M.Y. (2006), "Tourist local lore: textbook". Knowledge, Lviv.

11. Fomenko N.V. (2007), "Recreational resources and balneology." Center for Educational Literature, Kyiv. 